\title{
Reptiles in the Pontianak and Kubu Raya Residental Area, West Kalimantan, Indonesia
}

\author{
ANANDITA EKA SETIADI", HANUM MUKTI RAHAYU \\ Department of Biology Education, Faculty of Teacher Training and Education, Universitas Muhammadiyah Pontianak. Jl. Jend. A. Yani No. 111, \\ Pontianak 78123, West Kalimantan, Indonesia. Tel./fax.: +62-561-764571, `email: anandita.eka@unmuhpnk.ac.id.
}

Manuscript received: 9 February 2021. Revision accepted: 19 June 2021.

\begin{abstract}
Setiadi AE, Rahayu HM. 2021. Reptiles in the Pontianak and Kubu Raya Residental Area, West Kalimantan, Indonesia. Biodiversitas 22: 2763-2770. The increase in population is directly proportional to housing needs. Expansion of residential areas can threaten the diversity of reptiles in West Kalimantan. This study aims to inventory and identify the diversity of reptiles in residential areas in Pontianak and Kubu Raya, West Kalimantan province, Indonesia. This research gives a better understanding of reptilian urban species to support monitoring and evaluation of biodiversity in West Kalimantan. This research uses the descriptive exploratory method. Four study areas were selected based on a proportion of impervious surfaces. Data collection used the VES (Visual Encounter Survey). Identification refers to Reptile field guides and identification books. The data were analyzed descriptively qualitatively, the level reptile diversity was analyzed using the Shannon Diversity Index, and the similarities of reptiles between the residential area in Pontianak and Kubu Raya were assessed using the Jaccard similarity coefficient. The results showed, from 50 individual reptiles found in Pontianak and Kubu Raya, there were 13 reptile species from the order Squamata and the order Testudines. The Shannon-Wiener Diversity Index of 2.26 and Jaccard similarity coefficient 0.384 , indicating that the level of diversity of reptile species in the two study areas is classified as moderate.
\end{abstract}

Keywords: Reptile, residential areas, West Kalimantan

\section{INTRODUCTION}

The growing human population requires the extension of a residential urban area (Chi and Ventura 2011; Giyarsih and Alfana 2013; French et al. 2018; Putri et al. 2020). In the last two decades, inhabitants and expansion of the residential area in West Kalimantan increase rapidly (Population and Civil Registration Office of West Kalimantan Government 2020). The expansion impacts the narrowing of the natural habitat for the reptiles (Reyes-Puig et al. 2017; Leyte-Manrique et al. 2019; Samitra and Rozi 2020) and will continue to arise because several residential areas are built in the natural habitats of reptiles (Alves et al. 2012; Janiawati et al. 2016; Kusrini et al. 2020).

The dramatic change of ecosystem in residential areas conferred challenges for the wildlife (Soulsbury and White 2015; Birnie-Gauvin et al. 2016). Environmental pressures, competition, noises, contaminants, air, and light pollution, even invasive species make only a few reptiles will survive in the urban environment (Carpio et al. 2015; French et al. 2018). Even though, the residential area presents a shelter, lower predation rates, and access to abundant food for an adaptive reptile to thrive (Cassani et al. 2015; French et al. 2018; de Andrade 2019). Urban areas, with their highly transformed landscapes and rapid human-caused changes to local ecosystems, are accepted as a major driver of biodiversity change (Zari 2018).

Unique conditions of the residential area have an impact on the diversity of the reptiles. Meanwhile, species diversity can affect ecosystem services (Zeller et al. 2018).
Knowledge about biodiversity in a residential area can help urban policymakers to make the right decisions regarding land allocation for green spaces, design urban planning, and conserve biodiversity in an urban area (Kong et al. 2010; Rastandeh 2017; Zari 2018). The decisions must eliminate the conflict between requiring of wildlife species and what humans expect from ecosystem services (Soulsbury and White 2015; Kowarik et al. 2020). Accordingly, monitoring and evaluating biodiversity in the residential area is needed to support the management sustainable urban ecosystem.

Several studies on the diversity of reptiles in an around settlement in Indonesia have been reported in recent years. Janiawati et al. (2016) found 6 species of lizards and geckos in a settlements area at Gianyar Regency, Bali. Samitra and Rozi (2020) were reported 15 species of reptiles around the human settlements at Lubuklinggau City, South Sumatra. The study by Maulidi et al. (2019) and Noperese et al. (2019) in Landak Regency, West Kalimantan found 4 species of lizard in the settlement area at Parek Village and 2 species of reptiles in tourism site at Munggu Village. However, information regarding the diversity of reptiles in a residential area in Pontianak City and Kubu Raya Regency has never been reported. This study aims to inventory and identify reptile diversity in some residential areas in West Kalimantan province. Indonesia. This research gives a better understanding of reptilian urban species to supports monitoring and evaluation of biodiversity in West Kalimantan. 


\section{MATERIALS AND METHODS}

\section{Study area}

The study area was in residential area of Pontianak and Kubu Raya, Province of West Kalimantan, Indonesia. Locations were selected based on a proportion of impervious surfaces (e.g. houses, buildings, yards, roads, parking lots, and other infrastructures) and population density. Pontianak is represented as older residential with high population density $(5,999$ people per square kilometer) and more than $66 \%$ covered area with impervious surfaces. Meanwhile, Kubu Raya is represented as young residential, with low population density (83 people per kilometer square) and $9.7 \%$ covered area by in pervious surfaces (Statistics of West Kalimantan Province 2020a, b).

\section{Data collection}

Samplings were carried out from May to October 2020. Six observation points for each study area were selected using purposive sampling, and subjective placed based on public information on reptile presence. Visual Encounter Surveys (VES) were applied for observing the reptiles on four sites, by two observers for each site. Eight observers observed a total of twenty-four observation points. Each observation point was sampled twice (Day and night searching). Day searching was conducted from around 06.00 to 08.00 hours and night searching from 19.00 to 21.00 hours (West Indonesian Time).

\section{Identification and nomenclature}

We followed Liat and Das (1999), McKay (2006), Grismer (2011), Murphy and Voris (2014), and Das (2015) for identification, and then Uetz et al. (2021) for taxonomy and nomenclature.

\section{Data analysis}

The species diversity for each study area (residential areas) was determined by using the Shannon Wiener Index $\left(\mathrm{H}^{\prime}\right)$. The similarities of reptiles between the residential area in Pontianak and Kubu Raya were assessed using the Jaccard similarity coefficient (Shaheen et al. 2011). To limit the bias in the data, we were only used data individuals encountered from nature and removed data individuals from captivity.

\section{RESULTS AND DISCUSSION}

\section{Reptile diversity and similarity between residential areas}

We found 13 species of reptiles ( $\mathrm{n}=50$ individuals) from four sampling sites, consisted of three families of lizards (Agamidae, Gekkonidae, and Varanidae), two families of snakes (Homalopsidae and Phytonidae), and two families of turtle (Emydidae and Geoemydidae). One of them is non-native species. The diversity index is in the moderate criteria, with Shannon-Wiener Diversity Index (H') 2.21 and Jaccard similarity coefficient 0.384 (Table 2 and Table 3).

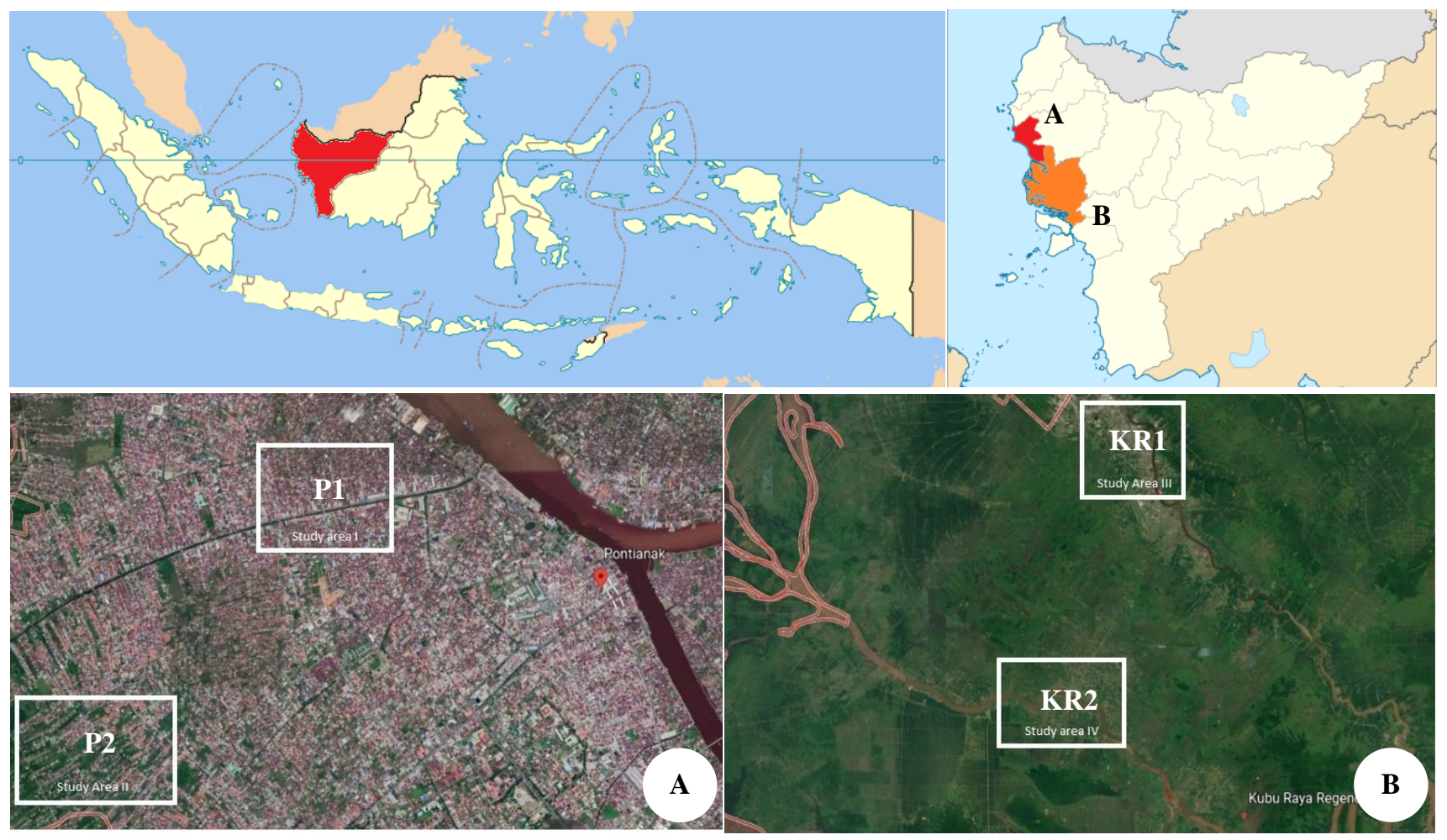

Figure 1. Site of field study in residential areas in Pontianak (A) and Kubu Raya (B) of West Kalimantan, Indonesia 
Tabel 1. The category and site of study area in residential areas of Pontianak and Kubu Raya, West Kalimantan, Indonesia

\begin{tabular}{|c|c|c|c|c|}
\hline Study area & Sites & Code & Category & Environment \\
\hline Pontianak & Study area I & P1 & $\begin{array}{l}\text { Urban housing with more than } 50 \% \\
\text { covered with impervious surfaces }\end{array}$ & $\begin{array}{l}\text { Houses are adjacent, generally without yards, around } \\
\text { building, roads, high traffic and light. }\end{array}$ \\
\hline Pontianak & Study area II & $\mathrm{P} 2$ & $\begin{array}{l}\text { Urban housing with less than } 50 \% \\
\text { covered with impervious surfaces }\end{array}$ & $\begin{array}{l}\text { Houses are relatively close, generally have yards, } \\
\text { around streets, open vegetation, medium traffic and light }\end{array}$ \\
\hline Kubu Raya & Study area III & KR3 & $\begin{array}{l}\text { Suburban housing with more than } \\
30 \% \text { covered with impervious } \\
\text { surfaces }\end{array}$ & $\begin{array}{l}\text { Houses are relatively close, generally have yards, } \\
\text { around streets, rivers, rice fields, plantations, open } \\
\text { vegetation, low traffic and light. }\end{array}$ \\
\hline Kubu Raya & Study area IV & KR4 & $\begin{array}{l}\text { Rural housing with less than } 5 \% \\
\text { covered with impervious surfaces }\end{array}$ & $\begin{array}{l}\text { Houses are far apart with large yards, around unpaved } \\
\text { roads, rivers, rice field, plantations, open vegetation, } \\
\text { low traffic and light. }\end{array}$ \\
\hline
\end{tabular}

Table 2. Number of individuals, species richness, diversity index, and similarity index of free-living reptiles in residential area in Pontianak and Kubu Raya, West Kalimantan, Indonesia

\begin{tabular}{lccc}
\hline & Pontianak & Kubu Raya & Both \\
\hline Number of individuals & 21 & 29 & 50 \\
Number of species & 6 & 12 & 13 \\
Families & 4 & 7 & 12 \\
$\mathrm{H}^{\prime}$ & 1.76 & 2.19 & 2.26 \\
$\mathrm{Cr}^{\prime}$ iteria H' & moderate & moderate & moderate \\
$\mathrm{S}_{\mathrm{j}}$ & & & 0.384 \\
\hline
\end{tabular}

Table 3. Reptiles in a residential area in Pontianak and Kubu Raya, West Kalimantan, Indonesia

\begin{tabular}{|c|c|c|c|c|c|}
\hline \multirow[t]{2}{*}{ Taxa } & \multicolumn{4}{|c|}{$\begin{array}{l}\text { Number of individual } \\
\text { in each study area }\end{array}$} & \multirow[t]{2}{*}{ Total } \\
\hline & P1 & $\mathbf{P 2}$ & KR3 & KR4 & \\
\hline \multicolumn{6}{|l|}{ Agamidae } \\
\hline Bronchocela cristatella & 0 & 0 & 2 & 0 & 2 \\
\hline \multicolumn{6}{|l|}{ Gekkonidae } \\
\hline Gehyra mutilata & 2 & 3 & 3 & 0 & 8 \\
\hline Gekko gecko & 0 & 0 & 1 & 1 & 2 \\
\hline Gekko monarchus & 2 & 2 & 0 & 0 & 4 \\
\hline Hemidactylus platyurus & 2 & 4 & 3 & 2 & 11 \\
\hline \multicolumn{6}{|l|}{ Varanidae } \\
\hline Varanus salvator & 0 & 1 & 1 & 3 & 5 \\
\hline \multicolumn{6}{|l|}{ Homalopsidae } \\
\hline Homalopsis buccata & 0 & 0 & 0 & 1 & 1 \\
\hline \multicolumn{6}{|l|}{ Phytonidae } \\
\hline Malayopython reticulatus & 0 & 3 & 1 & 1 & 5 \\
\hline Python breitensteini & 0 & 0 & 0 & 1 & 1 \\
\hline \multicolumn{6}{|l|}{ Emydidae } \\
\hline Trachemys scripta* & 0 & 0 & 1 & 0 & 1 \\
\hline \multicolumn{6}{|l|}{ Geoemydidae } \\
\hline Cuora amboinensis & 0 & 2 & 2 & 3 & 7 \\
\hline Cyclemys dentata & 0 & 0 & 1 & 1 & 2 \\
\hline Notochelys platynota & 0 & 0 & 0 & 1 & 1 \\
\hline Total & 8 & 13 & 15 & 14 & $\mathbf{5 0}$ \\
\hline
\end{tabular}

Note: *introduced species

\section{Species account \\ Lizards \\ Agamidae}

Bronchocela cristatella (KUHL, 1820) - Green crested lizard (Figure 2A). The species having a slender green body with a bluish tinge, the ventral body has a bright color. The head has a black orbit eye and black spot tympanum. Lizards have a light green throat pouch, a spiny triangular nuchal crest over the middle of the nape, and a long round tail. During a day, we found two adult lizards in a house yard over the shrubs and trees at study area III, Kubu Raya.

\section{Gekkonidae}

Gekko gecko (LINNAEUS, 1758) - Tokay gecko (Figure 2B). Commensalism. Snout vent length (SVL) reached $132 \mathrm{~mm}$. Tail length (TL) reached $180 \mathrm{~mm}$ The gecko has a large head, triangular with blunt snout. The pupil is vertical. The body is cylindrical with smooth skin, and the presence of tubercles along ventrolateral folds. The color is bluish-gray with reddish-orange spots on the dorsal, and light grey on the ventral. The gecko was found inside the houses, in the night, creeping on walls and ceilings. Based on interviews, we know that the geckos were hunted for sale in previous years, but when not sold, many geckos were released in residential areas, some were kept as a pet.

Gekko monarchus (SCHLEGEL, 1836) - Spotted house gecko (Figure 2C and Figure 2D). Snout vent length reached $81 \mathrm{~mm}$ and Tail length reached $85 \mathrm{~mm}$. The gecko has brownish-gray dorsal skin with a rough texture, there are 12 pairs of black spots lined up from the head to the middle of the tail. The head is triangular with "w" pattern. The young geckos are dark brown with whitish spots all over the dorsal surface. The eyes are yellowish. The tip of the finger extends with a webbed base. We found the geckos in the night at study area in Pontianak. The gecko was found at night hanging on the fence, and dead inside the building. According to residents, this species often found inside houses, on rocks, or on tree trunks.

Hemidactylus platyurus (SCHNEIDER, 1797) - Flattailed Gecko (Figure 2E). The gecko has medium or large body. The Rostral is square and slightly angled. Tympanum are small, oval and oblique. The dorsal generally grayishbrown with a marble hue that varies from light to dark. While the ventral tends to be lighter with a yellowish color. The body is flattened dorsoventrally with small scales on the dorsal side and widening at the head. In the posterior part of the hind limb (femur), there is also a widening of the skin overlapping ventral cycloid scales. The tail is flat 
with tapered sides covered by regular small scales. The center of the tail has transverse scales. The tail's central part has transverse scales - the leg with the membrane up to half the finger. We found house geckos in all study areas. Ten geckos were found at night, while the three others were found during the day. Geckos were found creeping on walls, on ceilings, on terraces, on fences, and in a crevice on the rocks.

Gehyra mutilata (Wiegmann, 1834) - Stump-tailed Gecko (Figure 2.F). The gecko has granular scales on the head, body, limbs, and tail. Greyish, light brown with a white spot on the dorsal and broken white on the ventral. No flaps of skin on body. Vertical pupils and tympanum medium or wide, semi-oval. First digit short. Claw small and concealed. Tapered thick rounded tail, covered by flat scales. We found eight house geckos in a night and day observation, in Pontianak and Kubu Raya, respectively in study areas I, II, and III. The geckos were found inside and outside the houses. Inside, we found this species creeping on walls, ceilings, behind cupboards and racks. Outside a house, we found it on terraces and fences.

\section{Varanidae}

Varanus salvator (LAURENTI, 1768) - Water monitor lizards (Figure 2.G). The species has a large body. The dominant color of the lizard is black with a circle pattern on the dorsal. The ventral body has a bright color. The head is oblong with a powerful jaw and a long forked tongue. This animal has strong legs and sharp claws. The long tail laterally compresses and has a dorsal keel. The tail strong and sturdy can be used for self-defense and support movement when swimming in water. In a day searching, we found one juvenile across the cement walkway in Pontianak, at study area II, the juvenile moved fast uncaught. In Kubu Raya, three lizards found around the houses near a river in study area IV during a night searching. One lizard found by a resident when entering his back yard at study area III. Based on interviews, the residents in study area IV said that the lizards frequently enter residential areas at night to prey on the fowl.

\section{Snakes \\ Homalopsidae}

Homalopsis buccata (LINNAEUS, 1758) - Puff-faced water snake (Figure 3A). The snake has wide triangular light brown head. Small eyes. The top of the snout has a black pattern. Body length 52 centimeters with grayishbrown based color. The snake has a brownish stripes pattern that convolute half of the body. The strips pattern throughout the length of the body to the tip of the tail. In a night observation, we found juvenile snake in shallow gutters in study area IV, Kubu Raya.

\section{Phytonidae}

Malayopython reticulatus (SCHNEIDER, 1801) Reticulated phyton (Figure 3B). The snake has yellow eyes with vertical pupils. The head has a black stripe, in the middle that extends into nape, that divides the two parts of the head symmetrically. Slim body and average length 2.3 meters. The snakes have grey or light brown base color with striking reticulation pattern, a large circle in the shape of a net, composed of black, brown, yellow, and white colors along the dorsal side of the body. We found snakes in Pontianak and Kuburaya, respectively in study area II, study area III, and study area IV. All the snakes were found at different points of observation. One month after the study was completed, one juvenile snake entered the house of the resident in study area II, it was caught by residents, and reported to us. We included it in the results because it was found in a residential area. According to the local resident, the snakes are often found among the bushes near the houses, sometimes it is hidden in the "longkang" (under the house).

Python breitensteini STEINDACHNER, 1881 Bornean short-tailed phyton (Figure 3C). This snake has a heavy body with fine blackish scales with reddish-brown blotches. The snakes found in litter leaves on the edge of the forest around the houses at study area IV, Kubu Raya.

\section{Turtles \\ Emydidae}

Trachemys scripta (THUNBERG in SCHOEPFF, 1792) - Red-eared slider (Figure 4A and Figure 4B). The turtle is an introduced species, it is not native to Kalimantan. The species has oval-shaped carapace with a slight indentation on the surface, and sharp edges. The adult carapace light brown with yellow lines, in a young individual, green with dark patches. The adult plastron is yellow with a pattern of green-brown circles. The head is striking yellow with red on the head's sides; at first glance, this red spot is like an ear. The limbs have membranes and claws with a distinctive green circle pattern in young individuals and brown in adults. We found the turtle in low moving water near the houses at study area III in Kubu Raya

\section{Geoemydidae}

Cuora amboinensis (DAUDIN, 1801) - Malayan box turtle (Figure 4C and Figure 4D). The species has an oval and tall carapace, dark black with three keels on the vertebral plate and smooth and flat edges. Plastron can be a tightly closed, broken white or cream with black spots on the edges. The head of Cuora amboinensis is black with yellow lines following the shape of the head. The yellow line runs through the neck, the upper head's edges, the eyelids and the snout. The iris is yellow. Cuora amboinensis limbs have a distinctive pattern of yellow lines on the fingers. We found seven turtles in Pontianak and Kubu Raya, respectively, in II, III, and IV. In the litter leaves of damp and bushes, in the riverside and the puddle near the houses. In accordance with the interview, the residents often see the turtles under "gertak" (bridge) when they wash the dishes in a river.

Cyclemys dentata (GRAY, 1831) -Asian Leaf Turtle (Figure 4E and Figure 4F). The turtles yellow-brown round slightly flat carapace. The vertebral carapace has five pieces keel, one-piece nuchal, four pieces costal, and twelve pieces marginal with darker serrations. The plastron is movable (has free moving hinge), with two triangular not protruding gular discs. Two elongate femoral discs. The pair anal discs with front edge arc-shaped. Yellow plastron 
has a black lines pattern arranged radially and slightly thickened. The head has red patches or stripes thin and almost invisible-black limbs with membranes and claws.
We found two turtles in Kubu Raya (study area III and study area IV), during a day in the river near the houses.
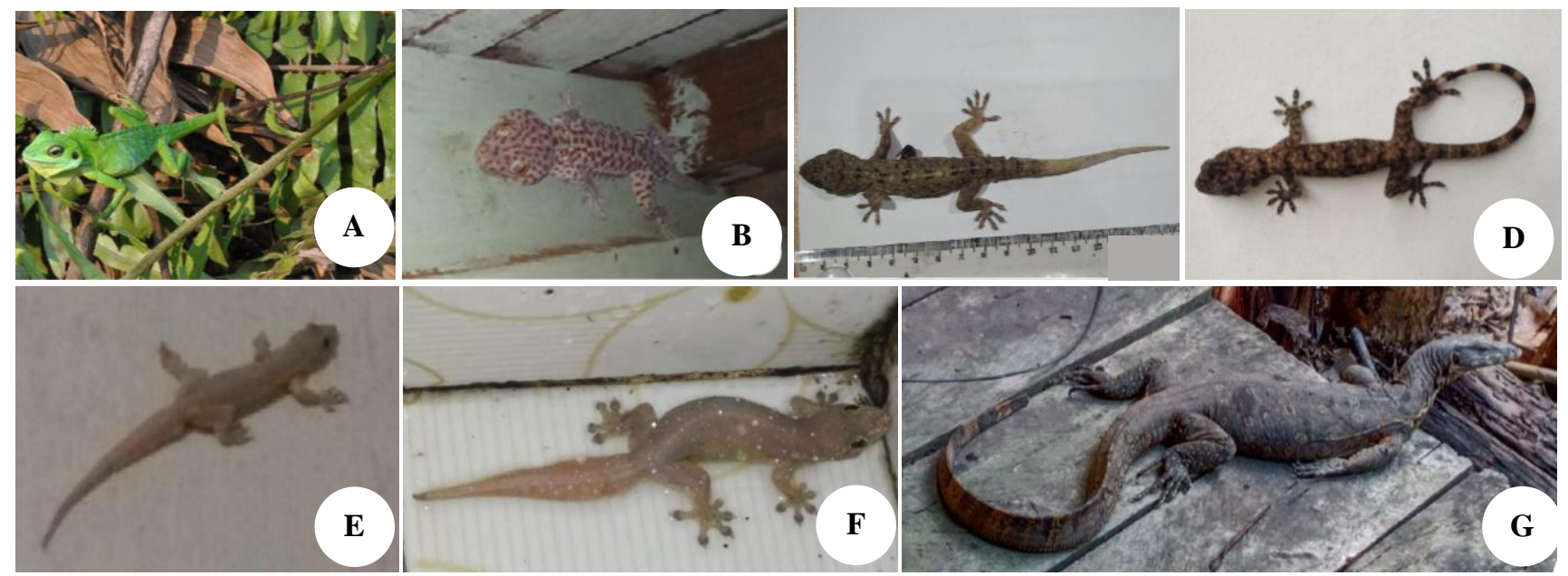

Figure 2. The lizards in Pontianak and Kubu Raya residential area, West Kalimantan, Indonesia. A Bronchocela cristatella, B Gekko gecko, C Adult Gekko monarchus, D Young Gekko monarchus, E Hemidactylus platyurus, F Gehyra mutilata, G Varanus salvator.

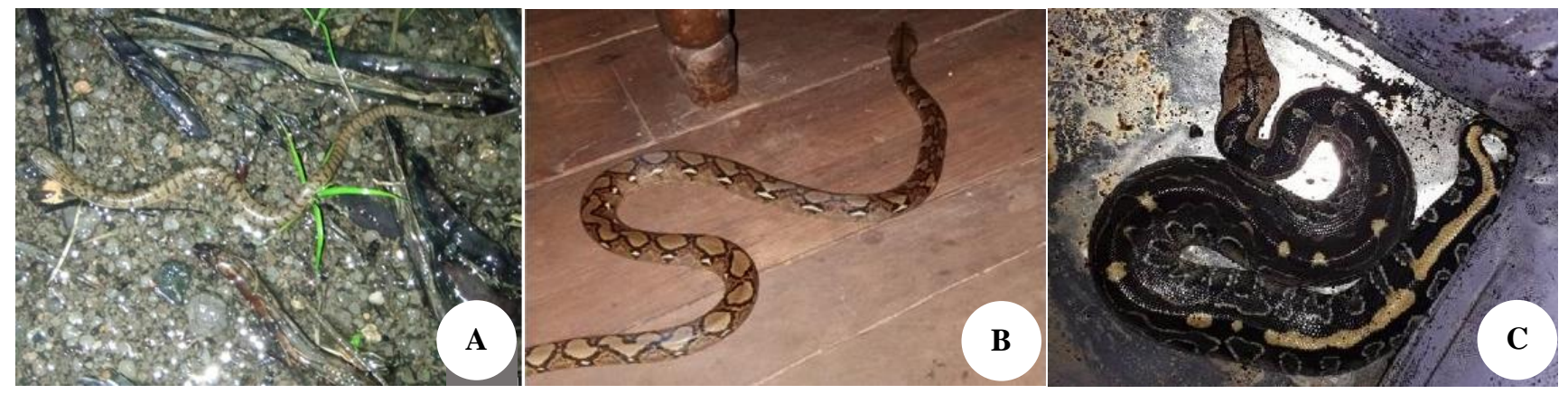

Figure 3. The snakes in Pontianak and Kubu Raya residential area, West Kalimantan, Indonesia. A Homalopsis buccata, B Malayopython reticulatus, C. Python breitensteini
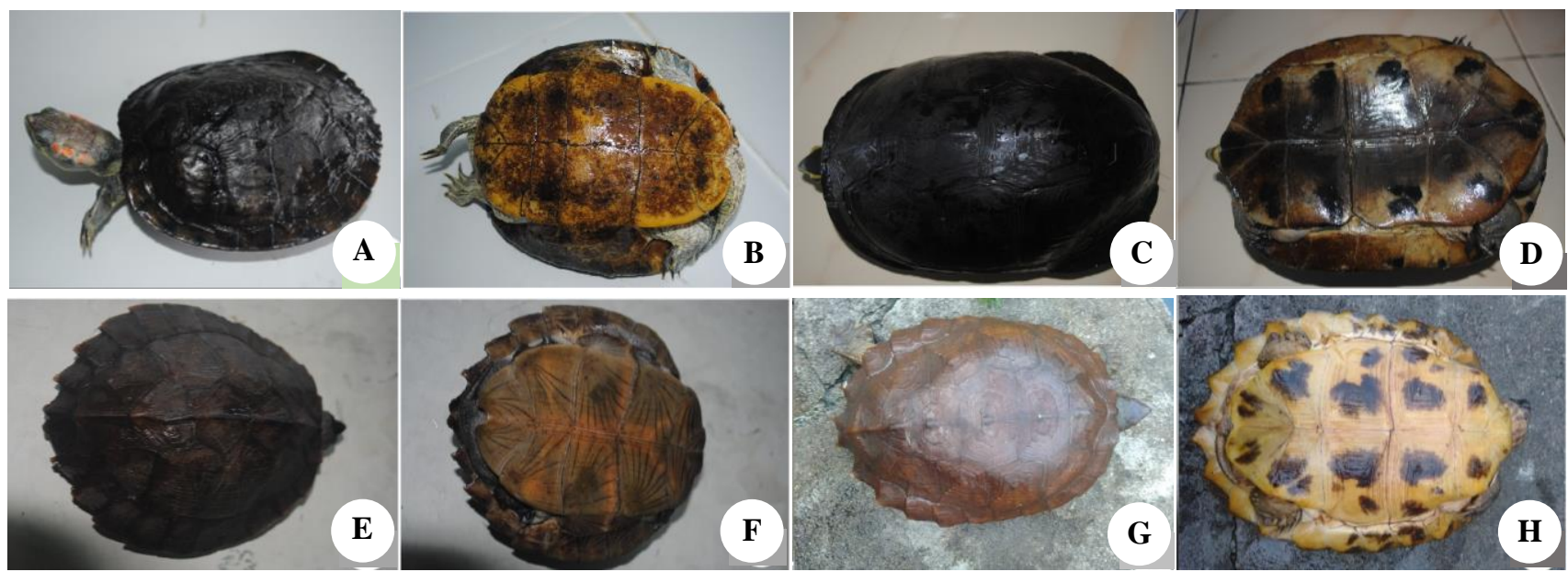

Figure 4. The turtles in Pontianak and Kubu Raya residential area, West Kalimantan, Indonesia. A Carapace Trachemys scripta, B Plastron T. scripta, C Carapace Cuora amboinensis, D Plastron C. amboinensis, E Carapace Cyclemys dentata, F Plastron C. dentata, G Carapace Notochelys platynota, H Plastron N. platynota. 
Notochelys platynota (GRAY, 1834) - Malayan flatshelled turtle (Figure $4 \mathrm{G}$ and Figure $4 \mathrm{H}$ ). The turtle that we found has a medium body size, body length $170 \mathrm{~mm}$. Brown head with a yellow stripe from the edge of the mouth to the neck. Snout slightly protruding. Reddishbrown oval carapace with radiation pattern. Six vertebral scutes have a keel in the middle, the first to fourth scutes being larger than the fifth and sixth. Plastron yellow with large dark spots on each scute. The toes are webbed. The tail is short and pointed. We found the turtle in the gutters during the day in Study Area IV, Kubu Raya.

\section{Discussion}

Thirteen species encountered around residential areas in Pontianak and Kubu Raya. The diversity index of the reptiles in residential areas in Pontianak and Kubu Raya is in the moderate criteria $\left(\mathrm{H}^{\prime}=2,26\right)$. We found five species of reptiles in both regions, they are Hemidactylus platyurus, Gehyra mutilata, Varanus salvator, and Malayopython reticulatus from the order Squamata, and Cuora amboinensis from order Testudines. Jaccard similarity coefficient of 0.384 indicates that residential areas in Pontianak and Kubu Raya share similarity of $38.4 \%$. However, the number of individuals, number of species, and diversity index of reptiles in Kubu Raya were higher than Pontianak. Seven species were only found in Kubu Raya, they are Bronchocela cristatella, Python breitensteini, Homalopsis buccata, Gekko gecko, Cyclemys dentata, Notochelys platynota, and Trachemys scripta. Meanwhile, Gekko monarchus was the only species found in Pontianak. Reptiles in residential areas are directly related to specific habitats and reptile activities, such as nesting, foraging, or basking (Borger et al. 2008; Saptalisa et al. 2015; Ali et al. 2018).

Study area I and II in Pontianak is residential area cover with building, houses, and street, this is a disturbing area with high traffic and light. In this study area, we found three scansorial geckos, $H$. platyurus, $G$. mutilata, and $G$. monarchus, creeping on the walls and ceilings. The geckos are well adapted to disturbed environments or habitats, the geckos naturally distributed around the house and coexist with humans (Eprilurahman 2012; Bucol and Alcala 2013; Barragan-Ramirez et al. 2015; Corona et al. 2018). The geckos commonly found around the human-made structure for foraging the insect (Badli-Sham et al. 2019).

In study area II, Pontianak, we found a juvenile lizard ( $V$. salvator) moving fast on paved roads. As nonterritorial varanids, $V$. salvator have a large home range, persistence in the disturbed area for opportunistic foraging nature (Arida 2008; Uyeda et al. 2012). In this area, we also find snake $M$. reticulatus and turtle $C$. amboinensis. We assumed that the lizard, snake and turtle used disturbed areas as a temporary habitat to avoid competition or to find food. The entry of these reptiles into residential areas in Pontianak may indicate that the residential area is a home range for these reptiles due to habitat loss, fragmentation, and landscape barriers that limit their space use. Urban populations may change animal spatial movement, particularly decreasing their home ranges, in response to habitat fragmentation, the presence of landscape barriers and the availability and density of resources (Pascoe et al. 2019; Averill-Murray et al. 2020; O'Donnell and DelBarcoTrillo 2020).

Study area III and study area IV in Kubu Raya is a residential area dominated with open vegetation and plantation It is semidisturbed area on forest edges surrounded by a river, rice field, and unpaved road. This area has low traffic and light. In this area, we found geckos, lizards, snakes, and turtles. The area provided breeding sites, sheltered and foraging ground for the reptiles. Occurrence indigenous reptiles are predicted, we found the geckos creeping on walls, trees, and a crevice on the rocks. Our finding accordance with Eprilurahman (2012), Weterings (2017), Davis et al. (2018), and Cruz et al. (2018) that the gecko naturally can be found in the areas of trees, rocks, and settlements. We found arboreal lizards, $B$. cristatella in scrubs and trees on the edge of the forest during a day, our finding fit with Das (2015), Grismer et al. (2015) and Yudha et al. (2016), that diurnal lizard favored basking in open area for thermoregulation. In a night observation, we found nocturnal reptiles, such as $V$. salvator around the houses near a river and juvenile $H$. buccata in shallow gutters that had lots of leaves near the landfill. Nocturnal reptiles are active at night for forage, they attracted to the disposal of food waste from residential areas (Uyeda et al. 2012; Murphy and Voris 2014; Setyawatiningsih et al. 2015; Davis et al. 2018). Cuora amboinensis unexpectedly found when residents wash dishes in the river, the turtle arises behavior to utilize food sources from scraps that enter the river when the locals wash the dishes. Our finding is evidence that $C$. amboinensis is a generalist species. A generalist species is a species that is capable of using a limited element and specific habitat (Hibbitts et al. 2013; Das and Gupta 2017).

We found non-native turtle, T. scripta, in low moving water near the houses in Kubu Raya. We presume that the T. scripta that we found was a loose pet and adapted well to the environment around the houses. The turtle is a worldwide invasive species, introduced in most freshwater habitats as a consequence of the exotic pet trade (Bohm 2013; Polo-Cavia et al. 2014). T. scripta is an opportunistic omnivore, consuming vegetation and soft-bodied insects (Stephen and Ryan 2019). Some kind of diet of T. scripta shared with native turtles like $C$. ambionensis, $C$. dentata, and $N$. platynota. In the future, if $T$. scripta thrives well in the natural environment, it is potentially to become a competitor for native turtles. Reduction of wild populations for pet trade and introduction of invasive alien species (IAS) from escapees or released animals can threaten the native species (Pasmans et al. 2017). On the other hand, we found the native exotic reptile, $G$. gecko and $P$. breitensteini. The two exotic reptiles have dealt with hunting in recent years. Even though in around residential area Kubu Raya we found this reptile as free living. We highly recommend evaluating the existence of these species in their natural habitat. The data can be used to generate a regulatory based on assessment and evidence. Policies and mechanisms need to be in place to strengthen biodiversity protection (Zari 2018; Mangalugiu et al. 2019). 


\section{ACKNOWLEDGEMENTS}

We thank M. Fadhillah, Yoga Febriyanda, Agung Setiawan, Irma Pibriyanti, Siti Munawaroh, Siti Amalia, Nurhayati, residents around Jalan Gajah Mada, Jalan Tanjung Pura, Jalan Karet, Jalan Pembangunan, sub-district Akcaya, Parit Tokaya, Kota Baru, Purnama, Parit Demang, Perdana, Sepakat, Sungai Beliung, housing complex Perumnas II, Arini Residen, Restu Perdana Residen, Village Sungai Itik, Parit Keladi, Sungai Ambawang, Rasau Jaya I and Rasau Jaya II, and all parties who have assisted in data collection. The manuscript was enhanced by comments from three anonymous referees on previous versions of this article. This work was supported by a Hibah Dosen from LPPM, Universitas Muhammadiyah Pontianak, Indonesia.

\section{REFERENCES}

Ali W, Javid A, Hussain A, Bukhari SM. 2018. Diversity and habitat preferences of amphibians and reptiles in Pakistan: A review. J Asia Pac Biodivers 11 (2): 173-187. DOI: 10.1016/j.japb.2018.01.009.

Alves RRN, Viera KS, Santana GG, Viera WLS, Almeida WO, Souto WM, Montenegro PFGP, Pezzuti JCB. 2012. A review on human attitudes towards reptile in Brazil. Environ Monit Assess 184: 6877 6901. DOI: $10.1007 / \mathrm{s} 10661-011-2465-0$

Arida E. 2008. An overview on the ecology of Varanid Lazards. Zoo Indon 17 (2): 67-82.

Averill-Murray R, Fleming CH, Riedle JD. 2020. Reptile home ranges revisited: A case study of space use of Sonoran desert tortoises (Gopherus morofkai). Herpetol Conserv 15 (2): 253-271.

Badli-Sham BH, Ayob M, Halim MFA, Mustafa SK, Ismail NF, Andam J, Belabut DM, Ahmad AB. 2019. Herpetofauna in Southern Part of Pulau Tioman, Pahang, Peninsular Malaysia. J Wildl Parks 34:23-38.

Barragan-Ramirez JL, Reyes-Luis OE, Ascencio-Arrayga JdJ, NavarreteHeredia JL, and Vasquez-Bolanos M. 2015. Diet and reproductive aspects of exotic gecko Gehyra mutilata (Weigmann, 1834) (Sauria: Gekkonidae) in urban area of Chapala Jalisco, Mexico. Acta Zoo Mex 31 (1): 67-73. DOI: 10.21829/azm.2015.311506

Birnie-Gauvin K, Peiman KS, Gallagher AJ, de Bruijn R, Cooke SJ. 2016. Sublethal consequences of urban life for wild vertebrates. Environ Rev 24: 416-425. DOI: 10.1139/er-2016-0029.

Bohm S. 2013. Records of invasive Trachemys scipta elegans (WiedNuewied, 1839), in cenotes of the Yucatan Peninsula, Mexico. Herpetozoa 26 (1/2): 98-100

Borger L, Dalziel BD, Fryxell JM. 2008. Are there general mechanisms of animal home range behaviour? A review and prospects for future research. Ecol Lett 11: 637-650. DOI: 10.1111/j14610248.2008.01182.x.

Bucol A, Alcala A. 2013. Tokay gecko, Gekko gecko (Sauria: Gekkonidae) predation on juvenile house rats. Herpetol Notes 6: 307308

Carpio AJ, Cabrera M, Tortosa FS. 2015. Evaluation of methods for estimating species richness and abundance of reptiles in olive groves. Herpetol Conserv Biol 10 (1): 54-63.

Cassani JR, Croshaw DA, Bozzo J, Brooks B, Everham EM, III, Ceilley DW, Hanson D. 2015. Herpetofaunal community change in multiple habitats after fifteen years in Southwest Florida Preserve, USA. PLoS ONE 10 (5): e0125845. DOI: 10.1371/journal.pone.0125845.

Chi G, Ventura SJ. 2011. Population change and its driving factor in rural, suburban, and urban areas of Wisconsin, USA 1970-2000. Intl J Popul Res 2011: 1-14. DOI: 10.1155/2011/856534.

Corona YM, Bustos-Zagal MG, Castro-Franco R, Trujillo-Jimenez P. 2018. The Asian house gecko Hemidactylus frenatus (Sauria: Gekkonidae), contributes to the control of Hematophagous mosquitoes in urban areas of the Mexican States of Morelos. Zool Sc 6 (1): 17-21.

Cruz PHPG, Afuang LE, Gonzales JCT, Gruezo WSM. 2018. Amphibians and reptiles of Luzon island, Philippines: The herpetofauna of
Pantabangan-Carranglan Watershed, Nueva Ecija Province, Caraballo Mountain Range. Asian Herpetol Res 9 (4):201-223. DOI: 10.3897/BDJ.7.e31638.

Das I. 2015. A Field Guide to the Reptiles of South-East Asia. New Holland Publisher, UK.

Das KC, Gupta A. 2017. An ecological note on the new record of Cuora Amboinensis (Riche in Daudin, 1801) (Reptilia: Testudines: Geomydidae) in Northeastern India. J Threat Taxa 9 (7):10459-10462

Davis HR, Grimser LL, Cobos AJ, Murdoch ML, Sumarli AX, Anuar S, Muin MA, Wood Jr P, Quah ESH. 2018. Checklist of the herpetofauna of hutan Lipur Gunung Senyum, Paham, Paninsular Malaysia. Russ J Herpetol 25 (3): 207-220. DOI: 10.30906/10262296-2018-25-3-207-220.

De Andrade Ac. 2019. Metropolitan lizards? Urbanization gradient and the density of lagartixas (Trapidurus hispidus) in a tropical city. Ecol Evol 00:1-11. DOI: 10.1002/ece3.5518.

Eprilurahman R. 2012. Cicak Dan Tokek Di Daerah Istimewa Yogyakarta. Fauna Indonesia 11 (2): 23-27. [Indonesian]

French SS, Webb AC, Hudson SB, Virgin EE. 2018. Town and country reptiles: A review of reptilian responses to urbanization. Symposium Behavioral and Physiological Adaptation to Urban Environments: The Society for Integrative and Comparative Biology, San Francisco, California, 3-7 January 2018. DOI: 10.1093/icb/icy052.

Giyarsih SR, Alfana MAF. 2013. The role of urban area as determinant factor of population growth. Indones J Geogr 45 (1): 38-47.

Grismer LL. 2011. Lizards of Peninsular Malaysia, Singapore and Their Adjacent Archipelagos. Edition Chimaira. Frankfurt am Main.

Grismer LL, Wood PL, Lee CH, Quah ESH, Anuar S, Ngadi E, Sites jr JW. 2015. An integrative taxonomic review of the agamid genus Bronchocela (Kuhl, 1820) from Peninsular Malaysia with description of new montane and insular endemics. Zootaxa 3948 (1): 001-023. DOI: 10.11646/zootaxa.1327.1.1.

Hibbitts TJ, Ryberg WA, Adam CS, Fields AM, Lay D, Toung ME. 2013. Microhabitat selection by a habitat specialist and a generalist in both fragmented and unfragmented landscapes. Herpetol Conserv Biol 8 (1): 104-113.

Janiawati IAA, Kusrini MD, Mardiastuti A. 2016. Structure and composition of reptile communities in human-modified landscape in Gianyar Regency, Bali. Hayati 23: 85-91. DOI: 10.1016/j.hjb.2016.06006.

Kong F, Yin H, Nakagoshi N, Zong Y. 2010. Urban green space network development for biodiversity conservation: Identification based on graph theory and gravity modelling. Landsc Urban Plan 95: 16-27. DOI: 10.1016/j.landurbplan.2009.11.001.

Kowarik I, Fischer LK, Kendal D. 2020. Biodiversity conservation and sustainable urban development. Sustainability 12(4964): 1-8. DOI: $10.3390 /$ su 12124964

Kusrini MD, Khairunnisa LR, Nusantara A, Kartono AP, Prasetyo LB, Ayuningrum NT, Faz FH. 2020. Diversity of amphibians and reptiles in various anthropogenic disturbance habitat in Nantu Forest, Sulawesi, Indonesia. J Manajemen Hutan Tropika 26 (3): 291-302. DOI: $10.7226 / \mathrm{jtfm} .26 .3 .291$.

Leyte-Manrique A, Buelna-Chontal AA, Torres-Diaz MA, BerriozabalIslas C, Maciel-Mata CA. 2019. A Comparison of amphibian and reptilian diversity between disturbedand undisturbed environment of Salvatierra, Guanajuanto, Mexico. Trop Conserv Sci 12: 1-12. DOI: 10.1177/1940082919829992.

Liat LB, Das I. 1999. Turtles of Borneo and Peninsular Malaysia. Natural History Publications (Borneo), Kinabalu.

Maulidi A, Jakaria M, Fitriyana N, Rizki M. 2019. Herpetofauna diversity at Munggu Village, Landak Regency, West Kalimantan Province, Indonesia. Biogenesis: J Ilm Biol 7 (2): 116-123. DOI: 10.24252/bio.v7i2.10072.

Mangalugiu D, Mukherjee N, Davies J, Goncalves LR, Hills J, McRae L, Dankelman I, Hammami S, Wright C, Zastavniouk C. 2019. Policies, Goals, objectives and Environmental Governance: An Assessment of their effectiveness. Cambridge University Press, UK.

McKay JL. 2006. A Field Guide to the Amphibians and Reptiles of Bali. Krieger Publishing Company, Florida.

Murphy JC, Voris HK. 2014. Fieldiana Life and Earth Science: A Checklist and Key to the Homalopsid Snake (Reptilia, Squamata, Serpentes), with the Description of New Genera. Field Museum of Natural History, Chicago, Illinois USA. DOI: 10.3158/2158-552014.8.1.

Noperese J, Yanti AH, Setyawati TR. 2019. Inventarisasi jenis-jenis kadal (Sub ordo Sauria) di kawasan hutan primer, hutan sekunder, dan 
pemukiman di Desa Parek Kecamatan Air Besar Kabupaten Landak. Protobiont 8 (2):62-68. DOI: 10.26418/protobiont.v8i2.33964.

O'Donnell K, DelBarco-Trillo J. 2020. Changes in the home range size of terrestrial vertebrates in response to urban disturbance: Meta-analysis. J Urban Ecol 6 (1) 1-8. DOI: 10.1093/jue/juaa014.

Pascoe JH, Flesch JS, Duncan MG, Le Pla M, Mulley RC. 2019. Territoriality and seasonality in the home range of adult male freeranging Lace monitors (Varanus varius) in South-Eastern Australia. Herpetol Conserv Biol 14 (1) 97-104.

Pasmans F, Bogaerts S, Braeckman J, Cunningham AA, Hellebuyck T, Griffiths RA, Sparreboom M, Schmidt BR, Martel A. 2017. Future of Keeping pet reptiles and amphibians: Towards integrating animal welfare, human health and environmental sustainability. Vet Rec Open 1:1-7. DOI: 10.1136/vr.104296.

Polo-Cavia N, Lopez P, Martin J. 2014. Interferences competition between native Iberian turtles and exotic Trachemys scripta. Basic Appl Herpetol 28: 5-20. DOI: 10.11160/bah.13014.

Population and Civil Registration Office of West Kalimantan Government. 2020. Population growth graph in West Kalimantan. https://dukcapil.kalbarprov.go.id [Indonesian]

Putri RF, Abadi AW, Tastian NF. 2020. Impacts of population density for land use assessment in Cengkareng, West Jakarta. JGEET 5 (2): 56 67. DOI: 10.25299 /jgeet.2020.5.2.3705.

Rastandeh A, Brown DK, Zari MP. 2017. Biodiversity conservation in urban environment: A review on the importance of spatial patterning of landscape. Ecocity World Summit, Melbourne, Australia, 12-14 July 2017.

Reyes-Puig C, Almendariz A, Torres-Carvajal O. 2017. Diversity, threat, and conservation of reptiles from Continental Ecuador. Amphib Reptile Conserv 11 (2): 51-58.

Samitra D, Rozi ZF. 2020. Short Communication: The herpetofauna around human settlements in Lubuklinggau City, South Sumatra, Indonesia: Composition and diversity. Biodiversitas 4: 1432-1437. DOI: $10.13057 /$ biodiv/d210422.

Setyawatiningsih SC, Arida EA, Solihin DD, Boediono A, Manalu W. 2015. Morphological variations of Varanus salvator macromaculatus
Deraniyagala, 1944 Among Population in Sumatera region. Zoo Indon 24 (2): 121-134. [Indonesian]

Shaheen H, Khan SM, Harper DM, Ullah Z, Qureshi RA. 2011. Species diversity, community structure, and distribution patterns in West Himalayan Alpine Pastures of Kashmir, Pakistan. Mt Res Dev 31 (2): 153-159. DOI: 10.1659/MRD-JOURNAL-D-10-00091.1.

Soulsbury CD, White PCL. 2015. Human-wildlife interaction in urban areas: A review of conflicts, benefits, and opportunities. Wildl Res 42 (7): 541-553. DOI: 10.1071/WR14229.

Statistics of West Kalimantan Province. 2020a. Population (people), 20172019. https://kalbar.bps.go.id [Indonesian].

Statistics of West Kalimantan Province. 2020b. People density (people per kilometer square), 2017-2019. https://kalbar.bps.go.id [Indonesian]

Stephens JD, Ryan TJ. 2019. Diet of Trachemys scripta (Red-eared Slider) and Graptemys geographica (Common Map Turtle) in an urban landscape. Urban Ecosyst 21: 1-11.

Uetz P, Freed P, Aguilar R, Hosek J (eds). 2021. The Reptile Database. http://www.reptile-database.org.

Uyeda LT, Iskandar E, Kyes RC, Wirsing AJ. 2012. Proposed research on home ranges and resource use of the water monitor lizard, Varanus salvator. For Chron 88 (5): 1-5. DOI: 10.5558/tfc2012-103.

Weterings R. 2017. Observation of an opportunistic feeding strategy in flat-tailed house gecko (Hemidactylus platyurus) living in buildings. Herpetol Notes 10: 133-135.

Yudha DS, Eprilurahman R, Jayanto H, Wiryawan IF. 2016. Diversity of Lizard and Snakes (Squamata: Reptilia) along Code River, Yogyakarta Special Province. Biota 1 (1): 31-38. DOI: 10.24002/biota.v1i1.710.

Zari MP. 2018. The importance of urban biodiversity-an ecosystem services approach. Biodivers Int J 2 (4): 357-360. DOI: 10.15406/bij.2018.02.00087.

Zeller U, Perry G, Gottert T (eds). 2018. Biodiversity and the urban-rural interface: Conflicts vs opportunities. Proceedings of An International Workshop in Linde, Germany, 24-27 September 2018. DOI: $10.18452 / 19995$. 